\title{
A Gender Analysis of the Great Recession and "Austericide" in Spain
}

Uma análise de género da Grande Recess

austericídio" em Espanha

Une analyse des questions de genre dans la grande récession et "austéricide" en Espagne

\section{Lina Gálvez and Paula Rodríguez-Modroño}

\section{(2) OpenEdition}

\section{Journals}

Electronic version

URL: http://journals.openedition.org/rccs/6492

DOI: $10.4000 /$ rccs. 6492

ISSN: 2182-7435

Publisher

Centro de Estudos Sociais da Universidade de Coimbra

\section{Printed version}

Date of publication: 1 December 2016

Number of pages: 133-152

ISSN: 0254-1106

\section{Electronic reference}

Lina Gálvez and Paula Rodríguez-Modroño, « A Gender Analysis of the Great Recession and "Austericide" in Spain », Revista Crítica de Ciências Sociais [Online], 111 | 2016, Online since 07 December 2016, connection on 30 April 2019. URL : http://journals.openedition.org/rccs/6492 ; DOI $10.4000 /$ rccs. 6492 


\section{LINA GÁLVEZ, PAULA RODRÍGUEZ-MODROÑO}

\section{A Gender Analysis of the Great Recession and "Austericide" in Spain}

This paper analyses the consequences of the latest recession and austerity measures for the working and living conditions of women and men in Spain, as well as the extent to which gender and other related inequalities are being modified or aggravated. Women are taking on additional responsibilities in terms of unpaid care work due to welfare cuts and privatization, while still facing discrimination in the labour market and in accessing resources and decision-making centres. This refamiliarization of care, together with increasing job insecurity, could have a major negative impact on the well-being of women and their present and future opportunities, which may endanger the fragile gains achieved in terms of gender equality.

Keywords: austerity; economic crisis; female discrimination; gender equality; Great Recession; labour market.

\section{Introduction}

Individuals are affected by economic crises - and by the economic policies implemented as a means of recovery - in very different ways, depending on their position and functions within the family, the labour market, society or the territory they inhabit In addition, all these differences and inequalities intersect with gender, leading to multiple discrimination. Hence, gender becomes a crucial analytical variable when studying how crises affect individuals. This is particularly true during an economic, social, and institutional crisis such as the one that has recently affected the global economy and is rooted in the rise of inequalities (Rajan, 2010; Stiglitz, 2012). However, the political response has been to deliver policies that, far from alleviating this growing inequality, have instead exacerbated it. This paper applies a gender analysis to the economic crisis in Spain (2008-2013) and the austerity measures implemented, since, in line with Rubery (2014: 17), "the relationship between gender, recession and austerity must be considered as historically and societally specific". 
The gender analysis of previous economic crises carried out by Gálvez and Rodríguez-Modroño (2012) highlights three key historic patterns or stylized facts that must be borne in mind when tackling the enduring gender inequalities in society in depth. The first pattern is associated with the fact that the means of recovery from crises involves an intensification of female labour, both paid and unpaid, which usually increases enormously during crises and recovery. This is because women's time, which is always seen as being more flexible, is the crux of the majority of family survival strategies and government strategies, particularly with regard to cuts in social services. Female labour creates the necessary flexibility for adjustments to the economic model in order to emerge from a crisis. The second historical pattern is that, after any crisis, male employment always recovers before female employment, which becomes even more precarious than it had been at the onset of the crisis. Thirdly, recovery from crisis entails backtracking on advances in equality achieved during boom periods with regard to regulation, policies and the "rules of the game". It would seem that in the context of deflationist economic policies, equality measures are considered completely dispensable.

However, the present crisis, which has become labelled a Great Recession, presents its own specificities. Previous crises hit societies in which women had not yet reached today's level of achievements in terms of education, involvement in the labour force, political representation or autonomy. Two other current features of western countries may also affect the gendered outcome of the Great Recession: the legacy of gender mainstreaming policies and the growing tertiarization of the economy. Tertiarization of the economy, together with the rise in women's educational levels and anti-discrimination policies, has made an important contribution to women's entry into the employment market. Moreover, the latest labour market reforms have cut salaries and increased insecurity and precariousness for men as well, thus supporting the trend towards dual-earner couples in order to guarantee decent household standards of living.

This might mean that the refamiliarization and privatization of care associated with austerity policies and welfare cuts, as well as the increasing precariousness of the labour markets, may not necessarily force women back into the home, or at least not all women. There is now greater diversity in opportunities and choices for women, and it is not yet known how this will affect gender stereotypes or what the cost will be in terms of demographics and the sustainability of social security systems.

In this respect, it is possible to identify gender not only as a relevant variable in assessing the outcomes of change but also as a factor that may 
shape the specific path of adjustments to recession and the sovereign debt crisis. As Rubery (2014: 18) states, this implies that "gender relations are both an input into and an outcome of the national model and the associated adjustment process". Thus, more needs to be learned about how women's vulnerability in recessions evolves and the economic responses that are decided (Karamessini, 2014).

This article examines transformations in the labour market, welfare system and gender order during the current crisis. The section which follows discusses the concept of austerity and its implications. Sections Three to Five analyse the three stylized challenges for gender equality that characterized the previous economic crisis in Spain. The sixth section introduces certain aspects that might counter the refamiliarization of women associated with the 'austericide' path taken by Europe, and particularly its peripheral countries, such as Spain. The article concludes with Section Seven.

\section{Austerity as a Moral Issue}

The link between economic crises and gender inequalities has been broadly studied from the perspective of feminist economics, particularly in relation to the processes of structural shrinkage experienced in Latin American and Asian countries in the 1980s and 1990s (see Elson, 2014 for a synthesis). This perspective brings into sharp focus gender interpretations of the Great Recession and the austerity option chosen by the majority of countries as a way out, particularly in Europe and chiefly in peripheral countries such as Spain. In fact, the notion of 'austerity' is merely a new label for old deflationist policies in which the economy adjusts by reducing wages, prices, and public spending (Blyth, 2013; Sotiropoulos et al., 2013). Austerity measures have been added to the market liberalization policies that were already in effect as a neoliberal response to the major structural crises of capitalism. The features of fiscal austerity programs since 2008 are also substantially similar to the structural adjustment plans of the 1980s and 1990s (Benería et al., 2015).

Nevertheless, labelling this 'austerity' introduces a sense of guilt that is passed on to society (Blyth, 2013). The argument is that fiscal deficits crowd out private investment and must be curtailed (Ostry et al., 2015). This explains how governments are capable of implementing fiscal retrenchment policies and cutting social spending with scarcely any adverse reaction from the public. It also explains how, right from the onset of the crisis, states have had little difficulty in freeing themselves from the obligation to provide public goods and services. In a context of crisis, equality and environmental policies have been considered 'the icing on the cake', 
which previous governments, particularly progressive ones, had worked into the scaffolding of their economic policies.

Anchoring economic policy in the struggle against debt - a debt that is attributed to social misbehaviour, thus generating a sense of guilt - essentially reinforces submission and therefore becomes a source for domination and hegemony in our time. This latter aspect has major consequences in terms of gender, since the new social contract derived from this situation is inseparable from a re-reading of women's role in society, in the market, and in the family. This is the new "austeritarian" version of deflationist policies, which implies that women return to the natural order of the home as guarantors of savings and protectors of the household. The vision proffered by such policies is that in recent years, when women have been totally or partially absent from their home as they entered the labour market, households have become a source of waste and extravagance, living beyond their means without the watchful care of women. Therefore, logically, women must now return to the home in order to provide the care that has been withdrawn by the new austerity regime. Hence austerity ultimately implies a new strategy for the provision of care services with very significant labour and gender consequences, although with differing results depending on the country and the situation of women with regard to the labour market, income levels, and education.

The implementation of economic policies that increase inequality and favour the growth of capital income at the cost of labour income can only be explained by a backslide in terms of commitment to equality, as well as a regression to more traditional gender norms. Austerity measures are clearly aligned with a conservative vision of society in which women are chiefly mothers and carers, and austerity is an excuse to implement anti-egalitarian legislation, just as the war on terror was the narrative that justified militaristic ventures, islamophobia, racism and support for authoritarian regimes. In both cases, a conservative agenda is advanced, arguing an urgent need for cuts and austerity measures (Michalitsch, 2011).

Although austerity policies have been imposed in over a hundred countries around the world (Ortiz and Cummins, 2013), the Eurozone has felt their effects particularly strongly, experiencing a second, politically induced recession when EU institutions opted for fiscal consolidation. Fiscal consolidation was implemented under the pretext of responding to the sovereign debt crisis in the European periphery, caused largely by the transfer of private debt to government balance sheets following the banking bailout. These policy measures have had a major impact on public expenditure cuts and on far-reaching structural reforms, and have been labelled 'austericide' 
because they undermine the foundations of the welfare state and entail the individualization and privatization of risk and contingencies faced by individuals during the course of their life, which encompass gender-related distinctions. Such austerity policies are helping financial entities to profit from the increase in debt, together with large companies, because both of them are global players whose profits do not depend on one or a few internal markets. They are also bolstering the political-economic oligarchy that slides through the revolving doors between governments and corporate boards, namely the top $1 \%$ of the population that captured $91 \%$ of the income gains in the first three years of the recovery. As Saez (2015) shows, the top $1 \%$ average real incomes per family in the US grew by $34.7 \%$ from 2009 to 2012 , while the bottom $99 \%$ incomes grew by only $0.8 \%$. Hence the term 'austericide' is entering into common parlance because of the damage it is doing to the economy, to democracy and to the well-being of the general population, particularly women.

\section{The Intensification of Female Labour and Vulnerability}

Past crises have revealed that the risk of female labour intensification is channelled through two routes: an increase in labour requirements linked to women's dual presence in the labour market and in unpaid family work (Benería et al., 2015) and the interaction between this dual presence, the increasing precariousness of labour markets and the disparate effects of new technologies.

Regarding the dual presence of women, during the recent crisis there has been an increase in female involvement in the labour force, and the added worker effect has been observed for women in the majority of advanced economies (Bettio et al., 2013; Karamessini and Rubery, 2014). The term 'added worker' refers to the incorporation of previously inactive segments of the population into the labour force. In this crisis, women have increased their presence in the labour force as a household strategy for coping with the loss of earnings caused by a partner's unemployment, resulting from the significant increase in unemployment in highly male-dominated industries, related to the high level of labour market segregation. The econometric analysis conducted by Addabbo et al. (2015a) for Spain shows a 21\% increase in female involvement in the labour force if the woman's partner is unemployed.

Figure 1 shows the strong added worker effect for Spanish women from the start of the crisis in 2008 up to 2013, just before the end of the recession. Nevertheless, since the second quarter of 2013, Spanish women have added to the discouraged worker effect, abandoning their search for employment 
given the lack of job opportunities. However, this is not to say that they are no longer engaging in largely informal activities that link them to the market, most of which are carried out within the domestic sphere in conjunction with unpaid care work (i.e. housework and child and adult care).

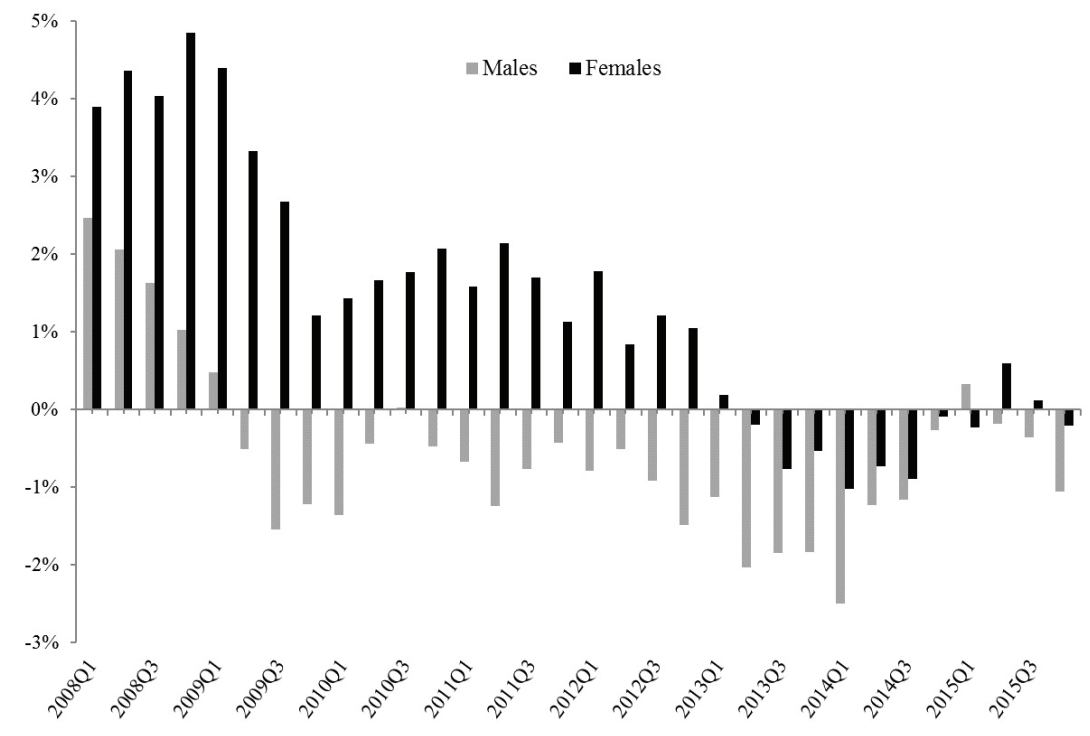

FIGURE 1 - Annual Variation in Labour Force Participation by Gender, 2008Q1-2015Q4 (in percentages)

Source: Labour Force Survey, Spanish Statistical Institute.

Moreover, economic crises lead to increases in unpaid care work that usually fall to women (Elson, 2010; Harcourt, 2009). Cuts in public spending on social services and care and a depressed family income result in increased home production of consumer goods and services. In the absence of equal sharing of the unpaid work burden, women are still primarily responsible for absorbing this growth in unpaid work. However, there are notable differences between women of different ages, different social strata or geographical areas which entail different patterns of outsourcing for the refamiliarization or reprivatization of care.

In the case of Spain, although the last Spanish Time Use Survey (STUS) dates from 2009-2010 and does not allow for a complete evaluation of the effect of austerity policies on the demand for unpaid care work, the available data already shows a more unequal gender distribution. The gender gap in 
total work has increased in Spain from 2002-2003 to 2009-2010 because although male employment was reduced, men have not taken on extra household and care tasks, as shown in the study by Giménez-Nadal and Molina (2014). ${ }^{1}$ Thus, in spite of the egalitarian trend in unpaid care work experienced in 2002-2003, with a slight reduction in the amount of female time (-16 minutes) and an increase in the average amount of time dedicated by men to such tasks ( +24 minutes), in $2009-2010$ more than $90 \%$ of Spanish women still devoted over 4 hours per day on average to household chores, in contrast to less than three quarters of men, who dedicated 2 hours 32 minutes on average.

The increase in unpaid family work during the current economic crisis could cancel out the positive trend towards a more egalitarian distribution between men and women in Spain. The rise in the burden of unpaid care responsibilities for women undermines their opportunities, since they enjoy less flexibility, mobility and, ultimately, less time to spend on training, actively seeking employment, or becoming involved in the active defence of their rights. The study conducted by Giménez-Nadal and Molina (2014) shows that unemployment leads to an increase in the time men devote to studying and leisure, whereas women increase the time they spend on unpaid care work, thereby reducing their chances of finding a job. Since they concentrate more on care work, women are more limited in terms of the types of employment they can access, their possibilities for professional development, and the opportunities they can enjoy throughout their lifetime.

Finally, changes in the labour market and industrial relations are involved in intensification of women's labour. The economic crisis has intensified the precarization of the labour markets by offering employers increased flexibility in terms of dismissals, working hours and overtime rates. Moreover, given the decline in wages and the increase in part-time contracts and hourly-paid jobs or services, many workers need to take on more than one job in order to earn the minimum that guarantees their material well-being and access to resources. Hence specific studies on work intensification in Great Britain that focus exclusively on the intensification that takes place in the labour market, such as Felstead et al. (2013), show how work intensification has resumed with the recession, due to increased competitiveness, rising levels of unemployment and greater fear in the workplace. The speed of work has increased and the pressures of working to tight deadlines have also risen to record highs. Work has intensified more sharply for women, and especially for women working full-time.

$\overline{1}$ Also in the US between 2007 and 2010 (Berik and Kongar, 2013). 


\section{The Slow Recovery of Female Employment and Precariousness}

The second stylized fact found when analysing economic crises is that once an economy begins to emerge and employment is being created, male employment always recovers first. In this respect, in the case of Spain, the recession does appear to have receded since the end of 2014, with positive figures registered for GDP growth, together with a very slow process of job creation. As in previous crises (Rodríguez-Modroño, 2012), this fragile recovery is greater in terms of male employment. This phenomenon has also been observed in countries that were quicker to emerge from recession, such as the US or the UK, where male employment began to recover in 2010 whereas female employment did not begin to do so until 2012.

\subsection{The Evolution of Unemployment for Men and Women during the Crisis and the Recovery}

As Figure 2 shows, during the first Spanish recession (2008-2009) unemployment increased dramatically, with more than 500,000 new entries in some quarters, mainly due to job losses, especially among men. The gender gap in unemployment rates was almost closed - although male levels were never higher than women's - owing to the massive loss of employment in male-dominated industries. Later, from mid-2009 to mid-2011, rising unemployment was somehow moderated by a less intense net job decline, fewer entries into the workforce and similar increases in women and men's unemployment rates. However, since the third quarter of 2011, Spain entered a second deep recession, with a decline in output rates from unemployment and the highest increases in unemployment of the crisis, fostered by austerity policies and labour market reforms. These reforms ${ }^{3}$ included easier and cheaper dismissals with reduced severance pay, new systems for flexible working hours, drastic reductions in overtime pay, and changes in collective bargaining rules (Rocha, 2014). Rising unemployment rebounded to around 200,000 people per quarter and female unemployment increased at a faster rate in many quarters, since austerity policies have targeted sectors in which women are over-represented (the public sector, social services, etc.). Since the last quarter of 2013, when a slow job recovery started, unemployment has been falling at a higher rate for men than for women.

\footnotetext{
${ }^{2}$ In the first two years of the US recovery, men saw faster job growth than women. However, by the third year of recovery, in 2012, there were marked gains in female job growth, which largely caught up with male growth. Within the fourth year of the recovery, the percentage of lost jobs regained by women overall exceeded that of lost jobs regained by men (Hartmann et al., 2014). 3 Royal Decree 10/2010, on measures to reform the labour market, which became Law 35/2010 of 17 September 2010, and Royal Decree 3/2012 of 10 February 2012, on urgent measures to reform the labour market, which became Law 3/2012 of 6 July 2012.
} 


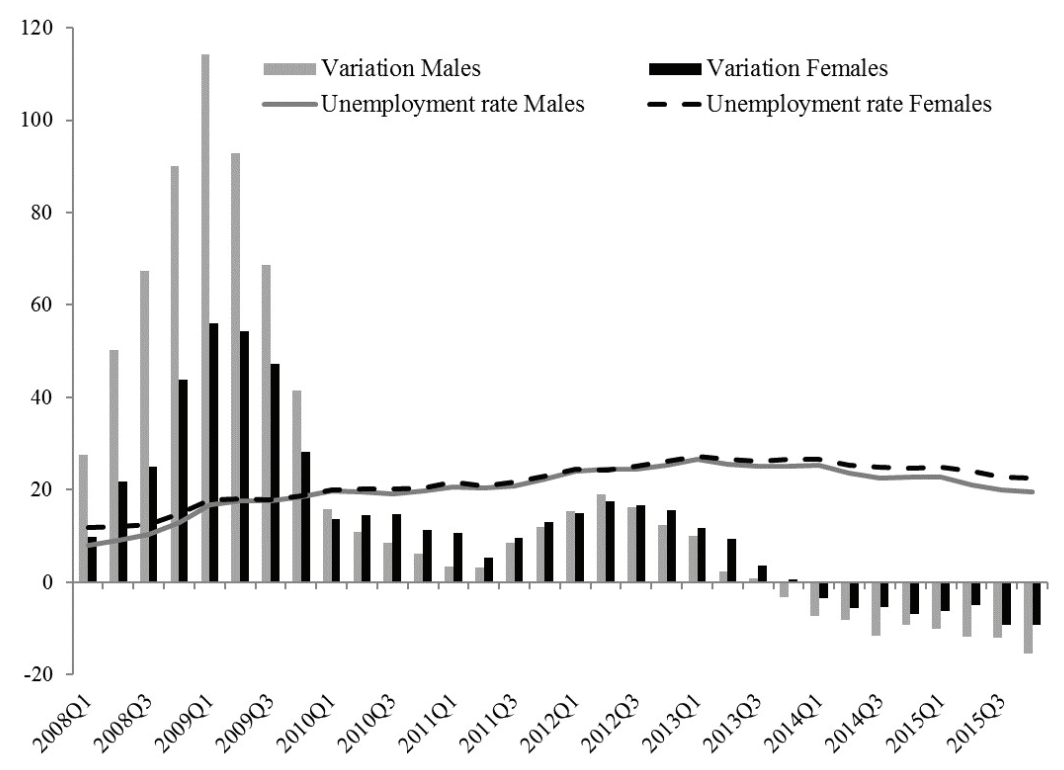

FIGURE 2 - Unemployment Rates and Annual Variation in Unemployed Population by Gender, 2008Q1-2015Q4

(in percentages)

Source: Labour Force Survey, Spanish Statistical Institute.

\subsection{Austerity Cuts in Public Services}

The higher losses in female employment in the latest stages of the crisis are due to the crisis spreading to the whole economy, as well as to 'gender blind' public policies. Public sector employment declined significantly from the second half of 2011 to the end of 2014 due to austerity policies (see Figure 3). Between 2010 and 2014, 233,000 public sector jobs were lost, an even greater amount than in the private sector. The slight recovery in public employment during 2015, an election year, compensates for less than half the previous job losses.

This loss of public sector employment has been damaging to women on three counts. Firstly, women make up the majority in the public sector, and are particularly concentrated in areas that have suffered the greatest cuts, such as social security, healthcare, and education. In fact, women outnumbered men in public sector job losses by 30,000 . Thus, shrinking public sector employment, together with pay cuts, freezes and deteriorating employment conditions in the public sector are having a negative impact on women (Rubery, 2015). Secondly, women are the main beneficiaries of the social transfers and public funding that are being eliminated or cut. 
Thirdly, women are the 'natural' substitutes when formal care provision by the state is eliminated. The Spanish long-term state care system has suffered severe budget cuts almost since its creation in 2007 and regional budgets have also been drastically reduced to meet the Stability and Growth Pact goals on public deficit, which is forcing regional governments to make cuts in education, healthcare, and minimum income and social inclusion programmes. As León and Pavolini (2014) state, regarding childcare and care for the elderly, Spain is reverting to assistentialism.

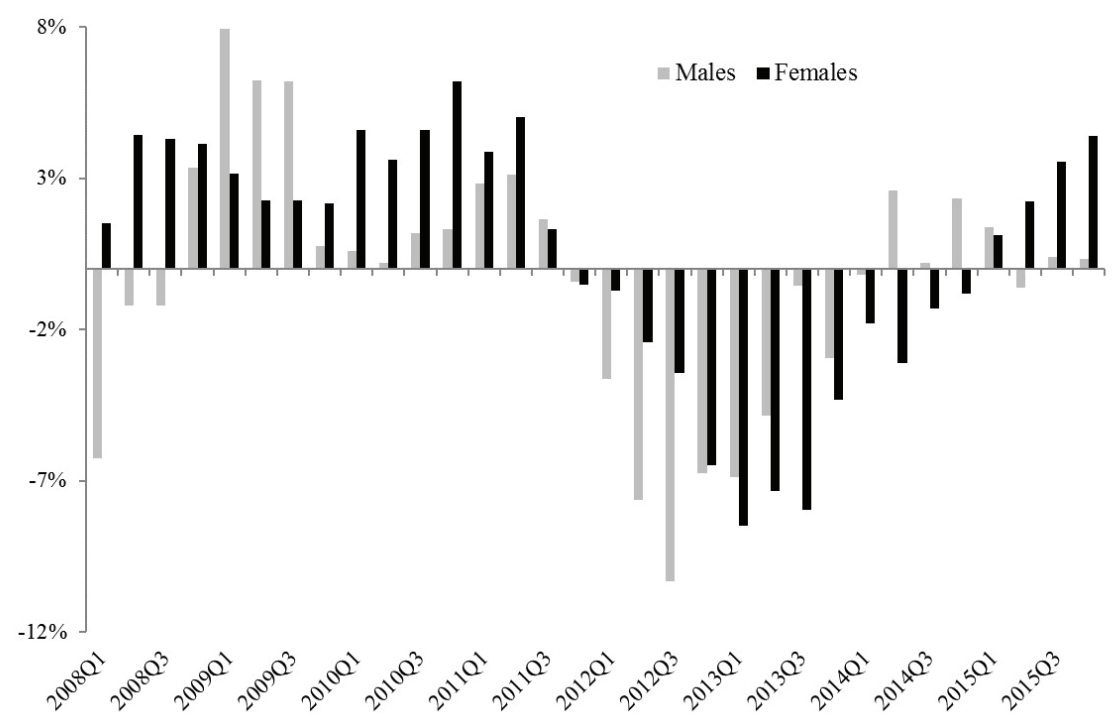

FIGURE 3 - Interannual Variation in Public Employment by Gender in Spain, 2008 Q1-2015 Q4

(in percentages)

Source: Labour Force Survey, Spanish Statistical Institute

Therefore, austerity policies are not only affecting the quantity and quality of jobs currently available in female-dominated industries but are also mortgaging the future possibilities for women's access to the labour market on an equal footing with men. In the words of Karamessini:

given that the public sector and social transfers and services have been key for women's economic integration and access to protected employment and good quality jobs from the Second World War onwards, austerity represents a major challenge for gender equality. (2014: 4) 


\subsection{Part-time Employment, Poverty and Lack of Autonomy}

Employment has become more precarious with the crisis. Part-time employment has increased both for women and men, but the percentage of Spanish women with part-time jobs has always been higher. According to Labour Force Survey data from Eurostat (2016), 25.1\% of employed women in Spain had part-time jobs in 2015, in contrast to just $7.8 \%$ of men. Moreover, $60.1 \%$ of women with part-time jobs are in this situation because they cannot find full-time employment, as opposed to $25.8 \%$ in the EU28. This paints a picture of underemployment and workers struggling to achieve enough economic autonomy to cope with life's daily needs.

The analyses conducted by Bardasi and Gornick (2008) for OECD countries, and by Del Río and Alonso-Villar (2010) for Spain, show the existence of a positive correlation between gender segregation and the weighting of part-time contracts. A large portion of the wage gap between women with full-time contracts and those with part-time contracts is due to the higher occupational segregation present in part-time employment. Hence, the increase in part-time contracts will exacerbate the gender labour segregation and aggravate the inequalities faced by women in terms of earnings and the risk of poverty. The hourly wage is lower in female part-time jobs than in full-time jobs and part-time employment shows the greatest gender wage gap. According to data from the Structure of Earnings Survey, Spain has one of the biggest gender wage gaps for part-time employment in the EU28 - 30.9\% in 2014, compared to $13.8 \%$ for full-time work - and a $12.2 \%$ in-work at-risk-of-poverty rate for women, in contrast to an average of $9 \%$ in the EU28 in 2014. Thus, the increase in female part-time employment may explain part of the increase in the at-risk-of-poverty rate for females, from $24.6 \%$ in 2007 to $28.9 \%$ in 2014 (SILC data from Eurostat, 2016). Part-time employment also implies lower possibilities for promotion and the development of a professional career.

The decline in opportunities for women to enter the labour market often translates into self-employment and entrepreneurship, which entails another transfer of responsibilities and risks onto workers, while at the same time blurring the figure of the business owner. The lower employment opportunities for women and the decline in female working conditions and earnings are necessarily linked to a loss of financial autonomy for women. Precarity, as a result of high unemployment rates and flexibilizing labour market reforms, has become a widespread phenomenon. These reforms have increased the scope for employers' discretion and flexibility, with a negative impact on women's employment. 
The loss in female financial autonomy not only undermines women's freedom but also investment in future generations and the sustainability of welfare systems in two ways. In the first place, the already low fertility rate of 1.44 at the start of the crisis in 2008 dropped to 1.27 in 2013, posing a serious threat to demographic sustainability and future pensions. Secondly, child poverty is the form of poverty that has increased most in Spain during the crisis. Capacities that are not developed during childhood are hardly developed when adults. Thus, child poverty implies a loss of individual and collective well-being in the future. Child development usually improves when mothers have their own earnings, because mothers are more altruistic towards children than fathers. ${ }^{4}$ Children's well-being is also affected by the reduction in time parents spend with their children because of the current trend towards work intensification.

\subsection{Precarity and Reinforcement of Gender Stereotypes}

The subsidiary nature of female labour and the precarious jobs of many women means that often their work is not even officially registered or declared, thus leading to a rising gender wage gap and a widening of the gender pension gap. In addition, the fewer chances of accessing employment and the precarious nature of their employment contribute towards reinforcing gender stereotypes and traditional gender roles.

This reinforcement of gender norms and stereotypes will have not only repercussions for women who are pushed out of the labour market because of the increased double or triple burden. It will also affect the other women, owing to what is known as statistical discrimination, which entails attributing the stereotypes of a group to the people who make up the group, without taking individual characteristics into account. This will help to reinforce the way in which the discrimination suffered by women within the family and in the market feed back into one another, since the reality will fuel the stereotype and the stereotype will strongly condition reality. As argued by Elson (2010), the degree to which economic crisis and the policy responses to it reinforce, destroy, or question existing gender norms is crucial and must be analysed in depth. Since the start of the current crisis, and in particular since 2010 as macroeconomic policy shifted towards fiscal austerity, we have been moving closer to an economic and social model based on inequality that is changing the rules of the game, including previous institutional advances in gender equality.

\footnotetext{
${ }^{4}$ See, for example, Thomas (1990), Bhalotra (2002), Pitt et al. (2003), Borderías et al. (2010), or Alger and Cox (2013).
} 


\section{Setbacks in Institutional Advances in Equality}

Analysis of past situations shows that economic crises lead to setbacks in certain advances in equality during periods of prosperity. Spain has seen systematic breaches of the 2007 Equality Act, the suppression in 2010 of the Ministry for Equality that had been created in 2008, the reduction of the budget for gender equality policies by more than half from 2008 to 2013, the disappearance of gender parity at governmental level, and the privatization and reduction of public services.

There have also been other deleterious measures, such as the suspension of subsidies for female employment and state incentives for companies that reincorporate women who have taken childcare leave. The 2012 Spanish Labour Reform also limits the right of workers to request a 'shorter working day' to care for children or dependents, and breastfeeding rights. Fathers have been entitled to two weeks of paternity leave since 2007, but the extension to four weeks due to be enforced in 2011 has been postponed.

As Karamessini (2014) points out, the current context raises the possibility of long-term retrenchment, even in welfare systems that are still underdeveloped, as is the case in Spain. Regressions may occur in the long term, due to the increased difficulty in achieving a work-life balance, the promotion of essentialist ideas of motherhood, and the loss of opportunities for women in terms of education, professional career, or motherhood (Gálvez, 2013). All of these risks are tied to an essentialist treatment of women as mothers, in which they are considered a means to other ends. Austerity may generate an ideological backlash which favours a return to traditional gender roles and backward-looking gender contracts. This is the subsoil on which the inferiority of women is constructed and the terrain is fertilized for gender violence.

Spain is not alone in experiencing this decline in gender priorities. In the 2008-2010 period of the Great Recession in Europe, the EU gender equality agenda faced a 'perfect storm', according to Villa and Smith (2014). The combination of the economic crisis and a major policy reformulation of the European Employment Strategy (EES) reinforced trends towards weakening commitments to gender equality goals, gender mainstreaming and the European social model.

\section{Differences from Previous Recessions}

Women as a whole have been spared from playing the role of buffer ${ }^{5}$ due to sectoral and occupational segregation, but also because they resisted leaving

\footnotetext{
${ }^{5}$ Rubery (1988) outlined three possible labour market outcomes for women during recessions: (i) the buffer hypothesis, in which female labour functions as reserve labour to be absorbed or expelled within boom and bust; (ii) women protected in less cyclical sectors because of gender segregation; (iii) a preference for hiring women over men to replace a high-cost workforce with a cheaper one (i.e. the substitution hypothesis).
} 
the labour market or else entered it despite adverse demand conditions. Forces which in other crises led to the total or partial exit of women from the labour market and to a return to the home are still present in the Great Recession, but certain structural changes are pushing in the opposite direction. Historically, women faced more limited labour opportunities, lower levels of education and training, and specialization in unpaid care. Their working activity was more dependent on their partner's involvement and performance in the labour market than the reverse (Gálvez and Rodríguez-Modroño, 2013). This resulted in low rates of activity and short, discontinuous working lives, with all the resulting consequences for well-being and professional development. However, the current economic recession is different from the previous ones in the 1980s and 1990s, given the changing position of women in the labour market and other gender differences. In brief, the four aspects that may be considered to be pushing in the opposite direction to the stylized facts found in previous crises, and which are patent in the case of Spain today, are higher levels of female education, the continuing demand for jobs in the tertiary sector with general qualifications that favour women, the path-dependence of equal opportunity policies, and the worsening labour market conditions.

In Spain, since 2001 more women than men have secondary or tertiary level educational qualifications. This increase in female human capital has not only improved women's prospects of being employed, under better conditions, but has also changed their expectations and life choices. The greater human capital accumulated by women is one of the forces that has the greatest potential to counter the potentially negative effects of privatization and refamiliarization of care in terms of professional opportunities for women. Nonetheless, the decline in employment opportunities in the public sector - a better employer for qualified women - may threaten the sorpasso achieved by women over men in education.

Secondly, one of the most important changes operating in western labour markets has been tertiarization. Whereas jobs in the industrial sector often require very specific training and qualifications, this is not the case in the services sector, where general qualifications are well regarded. This means that employers prefer a stable model for their workers, identified with males and with the real possibilities of men who, without commitments to any care work, can lead an uninterrupted working life. However, many jobs in the services sector do not require such a specific training, thus benefiting women who, through education, have gained more general qualifications and are less penalized in labour markets in the event of temporary or partial abandonment (Iversen and Rosenbluth, 2010). In addition, the deindustrialization 
of western societies has increased even more during the crisis, thus speeding up the rate of economic tertiarization.

Thirdly, regarding the legacy of equality policies, although the centrality of gender equality has disappeared from the EU strategy, the legacy endures in the decisions and expectations of women, and in the legislation previously adopted.

Finally, increasing job insecurity, which also affects men's jobs, may act as a factor that contributes to keeping women in the labour market due to the fact that it is impossible for a household to live on one single income. Gender relations may be shifting, both within the labour market and the home. The longstanding advantages of men over women in the labour market are declining, and women are becoming increasingly responsible for providing the household income (Duvvury and Finn, 2014). The continuing cuts in public expenditure relating to care, housing, and education profoundly affect women and their need to become increasingly involved in the labour market, even if this means facing precarious employment, working in the informal economy, or taking low-paid jobs (Girón and Correa, 2016).

We may therefore conclude that there are forces pushing in opposite directions which affect the decisions taken by women and men, especially young women and men (Addabbo et al., 2015b). However, these forces will affect women differently, depending on their educational level, class, family situation or attachment to the labour market.

\section{Conclusions}

The economic crisis - which has been used as an excuse to impose austerity throughout Europe, expand privatization of the public sector, and break up the previous social contract - is increasing economic inequality, whilst also reinforcing the risk of poverty and social exclusion for the majority of the Spanish population, in particular for women. Women still bear ultimate responsibility for the care of their families and when public services are cut, women frequently have to increase their hours of unpaid care work. Hence, efforts are geared towards imposing patriarchal norms that extol motherhood and traditional families.

However, there are also certain powerful forces that strive to keep women in the labour market: women's greater involvement and better position in the labour market; their higher levels of education; the ongoing tertiarization of the economy; the legacy of equality policies and feminist movements; the gender revolution in attitudes and behaviour; the widespread precariousness of the labour market, which necessitates several sources of income in order to maintain a family. 
In such a context, it is highly likely that within-group inequality for women will increase. Market expulsion forces will prevail in some cases and market maintenance forces will be dominant in others, in a very divisive way (O'Reilly and Nazio, 2014). However, it seems clear that women in particular will suffer from the shrinkage of the state and the individualization of risk, due to their central role as carers and their greater vulnerability in the labour market. If the state refrains from undertaking fiscal reforms to support the welfare system, families once again have to assume responsibility for care and inequality will increase. In the case of countries with underdeveloped welfare states and more patriarchal gender norms, such as Spain, we may therefore emerge from this crisis with a new gender order characterized by the intensification of women's work, the refamiliarization of care, inferior provisioning of care, precarious employment and living conditions, and the consequent loss of women's autonomy and agency. This process will also lead to an increased risk of poverty and exclusion, given that women are now making greater contributions to family income than ever before.

Revised by Sheena Caldwell

\section{References}

Addabbo, Tindara; Rodríguez-Modroño, Paula; Gálvez, Lina (2015a), "Gender Differences in Labor Force Participation Rates in Spain and Italy under the Great Recession”, Revista de Economía Mundial, 41, 21-42.

Addabbo, Tindara; Rodríguez-Modroño, Paula; Gálvez, Lina (2015b), "Young People Living as Couples. How Women's Labor Supply is Adapting to the Crisis. Spain as a Case Study”, Economic Systems, 39(1), 27-42.

Alger, Ingela; Cox, Donald (2013), "The Evolution of Altruistic Preferences: Mothers versus Fathers”, Review of Economics of the Household, 11(3), 421-446.

Bardasi, Elena; Gornick, Janet C. (2008), “Working for Less? Women's Part-time Wage Penalties across Countries", Feminist Economics, 14(1), 37-72.

Benería, Lourdes; Berik, Gunseli; Floro, Maria Sagrario (2015), Gender, Development and Globalization: Economics as if all People Mattered. New York and London: Routledge.

Berik, Guselli; Kongar, Ebru (2013), “Time Allocation of Married Mothers and Fathers in Hard Times: The 2007-09 US Recession”, Feminist Economics, 19(3), 208-223.

Bettio, Francesca; Corsi, Marcella; D’Ippoliti, Carlo; Lyberaki, Antigone; Samek, Manuela; Verashchagina, Alina (2013), The Impact of the Economic Crisis on the Situation of Women and Men and on Gender Equality Policies. Luxembourg: European Commission, Directorate-General for Justice. 
Bhalotra, Sonia Radhika (2002), "Parent Altruism”, Royal Economic Society Annual Conference, 25.

Blyth, Mark (2013), Austerity: The History of a Dangerous Idea. New York: Oxford University Press.

Borderías, Cristina; Perez-Fuentes, Pilar; Sarasúa, Carmen (2010), "Gender Inequalities in Family Consumption: Spain 1850-1930", in Tindara Addabbo; Marie-Pierre Arrizabalaga; Cristina Borderías and Alastair Owens (eds.), Gender Inequalities, Households and the Production of Wellbeing in Modern Europe. Farnham: Ashgate, 123-144.

Del Río, Coral; Alonso-Villar, Olga (2010), "Gender Segregation in the Spanish Labour Market: An Alternative Approach”, Social Indicators Research, 98(2), 337-362.

Duvvury, Nata; Finn, Caroline (2014), “'Man-covery': Recession, Labour Market, and Gender Relations in Ireland”, Gender, Sexuality E Feminism, 1(2), 59-81.

Elson, Diane (2010), "Gender and the Global Economic Crisis in Developing Countries: A Framework for Analysis”, Gender \& Development, 18(2), 201-212.

Elson, Diane (2014), "Economic Crisis from the 1980s to the 2010s: A Gender Analysis", in Shirin M. Rai and Georgina Waylen (eds.), New Frontiers in Feminist Political Economy. London: Routledge, 189-212.

Eurostat (2016), Labor Force Survey, Survey on Income and Living Conditions and Structure of Earnings Survey. Accessed on 17.05.2016, at http://ec.europa.eu/eurostat/data/ database.

Felstead, Alan; Gallie, Duncan; Green, Francis; Inanc, Hande (2013), Work Intensification in Britain. First Findings from the Skills and Employment Survey. Accessed on 11.06.2015, at http://www.cardiff.ac.uk/_data/assets/pdf_file/0006/118653/5. -Work-Intensification-in-Britain-mini-report.pdf.

Gálvez, Lina (2013), "Una lectura feminista del austericidio”, Revista de Economía Crítica, 15, 80-110.

Gálvez, Lina; Rodríguez-Modroño, Paula (2012), "La desigualdad de género en las crisis económicas”, Investigaciones Feministas, 2, 113-132.

Gálvez, Lina; Rodríguez-Modroño, Paula (2013), "El empleo de las mujeres en la España democrática y el impacto de la Gran Recesión”, Areas - Revista Internacional de Ciencias Sociales, 32, 105-123.

Giménez-Nadal, Jose Ignacio; Sevilla-Sanz, Almudena (2014), “Total Work Time in Spain: Evidence from Time Diary Data”, Applied Economics, 46(16), 1894-1909.

Girón, Alicia; Correa, Eugenia (2016), "Post-crisis Gender Gaps: Women Workers and Employment Precariousness”, Journal of Economic Issues, 50(2), 471-477.

Harcourt, Wendy (2009), "The Impact of the Crisis on Women in West Europe", Association for Women's Rights in Development Brief, 7.

Hartmann, Heidi; Shaw, Elyse; O'Connor, Rachel (2014), “Women and Men in the Recovery: Where the Jobs are. Women Recover Jobs Lost in Recession in Year Five”, Briefing Paper, C426. Washington DC: Institute for Women's Policy Research. 
Iversen, Torben; Rosenbluth, Frances (2010), Women, Work, and Politics: The Political Economy of Gender Inequality. New Haven, CT: Yale University Press.

Karamessini, Maria (2014), “Introduction - Women's Vulnerability to Recession and Austerity: A Different Crisis, a Different Context”, in Maria Karamessini and Jill Rubery (eds.), Women and Austerity. Croydon: Routledge, 3-16.

Karamessini, Maria; Rubery, Jill (eds.) (2014), Women and Austerity. Croydon: Routledge.

León, Margarita; Pavolini, Emmanuele (2014), “'Social Investment' or Back to 'Familism': The Impact of the Economic Crisis on Family and Care Policies in Italy and Spain”, South European Society and Politics, 19(3), 353-369.

Michalitsch, Gabriele (2011), “Austerity Promotes Gender Hierarchies”, Social Europe Journal, 22 February. Accessed on 10.04.2015, at http://www.social-europe.eu/2011/02/ austerity-promotes-gender-hierarchies/.

Ortiz, Isabel; Cummins, Matthew (2013), "The Age of Austerity: A Review of Public Expenditures and Adjustment Measures in 181 Countries”, Initiative for Policy Dialogue and the South Centre Working Papers. New York/Genève: Initiative for Policy Dialogue and the South Centre.

O'Reilly, Jacqueline; Nazio, Tiziana (2014), “Challenging the Balkanization of Gender Contracts", in Maria Karamessini and Jill Rubery (eds.), Women and Austerity. Croydon: Routledge, 36-53.

Ostry, Jonathan David; Ghosh, Atish Rex; Espinoza, Raphael (2015), "When Should Public Debt be Reduced?”, International Monetary Fund Staff Discussion Note $15 / 10$.

Pitt, Mark M.; Khandker, Shahidur Rahman; Chowdhury, Omar Haider; Millimet, Daniel L. (2003), "Credit Programs for the Poor and the Health Status of Children in Rural Bangladesh”, International Economic Review, 44(1), 87-118.

Rajan, Raghuram Govind (2010), Fault Lines: How Hidden Fractures still Threaten the Global Economy. Princeton, NJ: Princeton University Press.

Rocha, Fernando (2014), "Crisis and Austerity Policies in Spain: Towards an Authoritarian Model of Industrial Relations”, in Fernando Rocha (ed.), The New EU Economic Governance and its Impact on the National Collective Bargaining Systems. Madrid: Fundación 1. ${ }^{\circ}$ de Mayo, 175-206.

Rodríguez-Modroño, Paula (2012), "Tipología de perdedoras en las crisis económicas de los siglos XX y XXI”, Actas de XIII Jornadas de Economía Crítica, 530-544.

Rubery, Jill (1988), Women and Recession. London: Routledge.

Rubery, Jill (2014), "From 'Women and Recession' to 'Women and Austerity': A Framework for Analysis", in Maria Karamessini and Jill Rubery (eds.), Women and Austerity. Croydon: Routledge, 17-36.

Rubery, Jill (2015), “Austerity, the Public Sector and the Threat to Gender Equality”, The Economic and Social Review, 46(1), 1-27. 
Saez, Emmanuel (2015), "Striking it Richer: The Evolution of Top Incomes in the United States (Updated with 2013 Estimates)”. Accessed on 16.05.2016, at http:// eml.berkeley.edu/ saez/saez-UStopincomes-2013.pdf.

Sotiropoulos, Dimitris P.; Milios, John; Lapatsioras, Spyros (2013), A Political Economy of Contemporary Capitalism and its Crisis: Demystifying Finance. New York: Routledge.

Stiglitz, Joseph (2012), The Price of Inequality: The Avoidable Causes and Invisible Costs of Inequality. New York: Norton.

Thomas, Duncan (1990), "Intra-household Allocation: An Inferential Approach”, Journal of Human Resources, 25(4), 635-664.

Villa, Paola; Smith, Mark (2014), "Policy in the Time of Crisis: Employment Policy and Gender Equality in Europe”, in Maria Karamessini and Jill Rubery (eds.), Women and Austerity. Croydon: Routledge, 273-294.

Received on 01.02.2016

Accepted for publication on 11.05.2016

\section{Lina Gálvez}

Department of Economics, Quantitative Methods and Economic History, Universidad Pablo de Olavide

Ctra. de Utrera, km. 1 41013, Sevilla, Spain

Contact: lgalvez@upo.es

\section{Paula Rodríguez-Modroño}

Department of Economics, Quantitative Methods and Economic History,

Universidad Pablo de Olavide

Ctra. de Utrera, km. 1 41013, Sevilla, Spain

Contact: prodmod@upo.es

\section{Uma análise de género da Grande Recessão e do "austericídio" em Espanha}

Este artigo analisa as consequências da última recessão e das medidas de austeridade nas condições de vida e de trabalho das mulheres e dos homens em Espanha. Questiona até que ponto se têm alterado e agravado desigualdades como as de género. Defende que as mulheres assumem

\section{Une analyse des questions de genre dans la grande récession et "austéricide" en Espagne}

Cet article analyse les conséquences des dernières mesures de récession et d'austérité sur les conditions de vie et de travail d'hommes et de femmes en Espagne et jusqu'à quel point le genre et autres inégalités s'y rapportant se sont modifiés ou aggravés. Les femmes prennent des 
atualmente responsabilidades adicionais prestando trabalhos não remunerados devido a cortes sociais e a privatizações, ao mesmo tempo que continuam a enfrentar a discriminação no mercado de trabalho e no acesso a centros de recursos e de decisão. Defende que esta refamiliarização na prestação de cuidados, em simultâneo com a precariedade laboral, pode ter um impacto negativo muito forte no bem-estar das mulheres e nas suas oportunidades presentes e futuras, colocando em risco os frágeis ganhos alcançados até aqui em termos de igualdade de género.

Palavras-chave: austeridade; crise económica; discriminação da mulher; Grande Recessão; igualdade de géneros; mercado de trabalho. responsabilités additionnelles en ce qui concerne le travail de prestation de soins non rémunéré à cause des réductions dans les apports de la sécurité sociale et des privatisations, tout en continuant à faire face à des discriminations dans le marché du travail et dans l'accès aux ressources et aux centre de prise de décision. La re-familiarisation des soins, jointe à l'insécurité de plus en plus marquée de l'emploi peut avoir un impact négatif important sur les femmes et sur leurs opportunités présentes et futures capables de mettre en danger les fragiles acquis obtenus en termes de égalité de genre.

Mots-clés: austérité; crise économique; discrimination des femmes; égalité entre les femmes et les hommes; grande récession; marché du travail. 